\title{
Study of Selection Parameters for Different Yield and Juice Quality Parameters in Sugarcane (Saccharum sp. complex)
}

\author{
Tabassum*, A.S. Jeena, Deepanker Pandey, Deepak Koujalagi and S.P. Singh \\ Department of Genetics and Plant Breeding, College of Agriculture, Govind Ballabh Pant \\ University of Agriculture and Technology, Pantnagar, U.S. Nagar, 263145, \\ Uttarakhand, India \\ *Corresponding author
}

\section{A B S T R A C T}

Keywords

Saccharum officinarum, GCV, PCV, Heritability in broad sense, Genetic advance as percent mean

Article Info

Accepted: 10 May 2019 Available Online: 10 June 2019
This study was conducted to have basic information about the genetic nature of variation present in the clonal population of sugarcane. For this mean, range, genotypic coefficient of variation, phenotypic coefficient of variation, broad sense heritability and genetic advance was calculated using 144 sugarcane clones along with five standards in augmented block design. All the clones were differed significantly for all the 13 traits indicating that sufficient amount of variability was present in the experimental material. Most of the traits recorded a very wide range which indicates the level of variation present in the population. Higher GCV and PCV values were observed for traits namely no of millable canes, Cane yield and CCS yield whereas moderate values were observed for No of tillers, Single cane weight, and CCS\%. Higher broad sense heritability and GAM estimates were recorded for no of tillers, no of millable canes, single cane weight, cane yield and CCS yield. The narrow difference between GCV and PCV values indicates that these traits were less influenced by the environment. Hence, improvement through direct selection could be possible for these traits.

\section{Introduction}

Sugarcane is an important cash crop cultivated in tropical and sub- tropical regions of the world. Its ability to store high concentrations of sucrose in the stem and utilization for the production of an important renewable bio-fuel, ethanol made it more valuable crop plant (Sharma and Tamta, 2015). Globally, sugarcane is an important source of commercial sugar accounting for almost two thirds of world sugar production
(Menossi et al., 2008). India is the second largest producer of sugarcane and is the largest consumer of sugar in the world. Sugarcane belongs to genus Saccharum of tribe Andropogoneae, sub-tribe Saccharineaein family Poaceae. There are three recognized cultivated species namely Saccharum officinarum (noble cane, $2 \mathrm{n}=80$ ), Saccharum barberi $(2 \mathrm{n}=82-124)$, and Saccharum sinense and two wild species namely Saccharum spontaneum $(2 \mathrm{n}=40$ $128)$ and Saccharum robustum $(2 \mathrm{n}=60-194)$ 
(Gupta et al., 2010). Saccharum species complex is widely cultivated in India after nobalization because of high sucrose content and adaptability to adverse environmental conditions.

Sugarcane is cultivated in most of the states of India viz., Uttar Pradesh, Maharashtra, Karnataka, Tamil Nadu, Bihar and Andhra Pradesh etc. It is the second most important agro-industrial crop in India, next only to cotton (Jayashree et al., 2010). In India during 2017-18, sugar production was recorded 32137 thousand MT from an area of 4774 thousand hectares with $74.4 \mathrm{MT} / \mathrm{ha}$ cane yield. Sugar recovery was recorded to $9.30 \%$. Uttar Pradesh has the largest area (2234 thousand ha) under sugarcane cultivation during the period among different states cultivating sugarcane and Kerala (122 tonnes/ha) was recorded with highest sugarcane yield (Sugar India, 2018).

Being a complex dependent polygenic trait yield greatly influenced by the environmental fluctuations and is depend on many contributing traits. Direct selection for yield may produce misleading results. Therefore, knowledge on various genetic variability parameters is crucial, much valuable and play important role for shaping new varieties (Tabassum et al., 2017). It is evident that all the cultivated varieties of sugarcane are complex polyploids and heterozygous and generates great amount of genetic variability after crossing. The information on the nature and the magnitude of variability present in the genetic material is of prime importance for a breeder to initiate any effective selection programme. The tendency of individuals in a population to vary from one another referred as Genetic variability. The actual amount of phenotypic variation seen in a particular population is different from genetic variation. Therefore, for better selection it is essential to divide the present variability into its heritable and non-heritable components by estimating phenotypic and genotypic coefficient of variations (Singh et al., 2015). Genotypic coefficient of variability gives the magnitude of genetic variance present in the population. Heritability denotes the proportion of phenotypic variance that is due to genotype, i.e., heritable and is act as a tool to predict the gain from selection in a population i.e., genetic advance. Genetic advance is also important as it indicates the magnitude of the expected genetic gain from one cycle of selection (Pandey et al., 2018). Knowledge about all these selection parameters plays a crucial role to improve any trait of sugarcane. Therefore, present research was conducted to estimate the degree of genetic variability, heritability and genetic advance in different sugarcane genotypes for better cane yield, sugar yield and other attributing traits.

\section{Materials and Methods}

The present investigation was conducted at Sugarcane Breeding Block, Norman E.Borlaug Crop Research Centre, G.B. Pant University of Agriculture and Technology, Pantnagar with $144 \quad \mathrm{C}_{2}$ clones of general collection and bi-parental progenies of sugarcane and 5 check varieties. The experiment was conducted in Augmented Block Design using six blocks and each entry was allotted to a single row plot measuring $5.0 \mathrm{~m}$ long and plot to plot spacing was kept $0.90 \mathrm{~m}$. The observation were recorded on eight traits including morphological as well as juice quality parameters viz., germination percentage, no. of tillers/plot, no. of millable canes/plot, cane height, cane diameter, single cane weight, juice brix percentage, polarity and Cane yield per plot. No. of tillers/plot and no. of millable canes/plot were converted into thousand per hectare. Four traits viz., juice sucrose percent in juice, juice purity percent, commercial cane sugar percent and commercial cane sugar yield were calculated 
from measured traits using the following formulas-

\section{Sucrose percent in juice}

The sucrose percent in juice was noted for corresponding values of the brix and pol reading using Schmitz table (Spencer and Meade, 1955) for all the clones studied.

\section{Juice purity percent}

Purity $\%=\frac{\text { Juice Sucrose }}{\text { Juice Brix }} \times 100$

\section{Commercial cane sugar (CCS) percent}

$\operatorname{CCS} \%=[S-(B-S) \times 0.40] \times 0.73$

Where,

$\mathrm{S}=$ Sucrose percent in juice

$\mathrm{B}=$ Brix percent in juice

\section{Commercial cane sugar (CCS) yield ( $\mathrm{t} / \mathrm{ha})$}

CCSyield $(\mathrm{t} / \mathrm{ha})=\frac{\text { Available sugar }(\%) \text { in cane } X \text { Cane yield }(\mathrm{t} / \mathrm{ha})}{100}$

\section{Statistical analysis}

Statistical analysis involves analysis of variances for augmented block-II design (Federer, 1956) which allows evaluation of large breeding materials by spreading equal no of treatments over the blocks (b) with a set of checks (c) replicated in each block.

Both genotypic and phenotypic coefficients of variability were calculated for each trait according to the method given by Burton and De Vane (1953).

Heritability was calculated in broad sense by using formula given by Lush (1949). Genetic advance (GA) for each trait was calculated by formulae given by Johnson et al., (1955).

\section{Results and Discussion}

The results of analysis of variance for augmented design are summarized in Table 1. Analysis of variance indicated significant differences among all 144 C2 clones alongwith five standards for all the thirteen traits recorded. The mean square variances for germination percentage (45.899), no of tillers (344.154), no of millable canes (255.876), Single cane weight (0.044), polarity (47.047), Sucrose \% (2.706), purity \% (54.127), CCS\% (2.556), cane yield (381.215), CCS yield (14.421) were highly significant and for Cane height (0.112) significant mean square value was observed. The significant differences among entries for all the traits studied implies the presence of substantial variation which provides ample scope for the selection of superior and desirable clone and gives an opportunity to a plant breeder for improvement of these traits through breeding. Earlier workers Pandey et al., 2018 and Bairwa et al., 2017 reported high variability for these traits in sugarcane. The genetic variability parameters studied in $\mathrm{C} 2$ clonal population are presented in Table 2 .

\section{Mean and Range}

The simplest way for assessing variability is by examining the range of variation present. The variability for most of the traits such as germination percent, No of tillers, NMC, Cane height, Cane diameter, Brix\%, Sucrose $\%$, Purity \%, Cane yield and CCS yield indicated higher mean and wider range under evaluation. No of tillers (48.89-140.00), NMC (37.78-128.89), Single cane weight (0.701.80), Cane height (1.48-3.17), Sucrose \% (13.26-21.47) and Cane yield (39.11-140.00) recorded a very wide range which indicates the level of variation present in the population. More no of millable cane, cane height and single cane weight are important to obtain good cane yield. A wide range present 
for all the character aid to selection as wider range gives chance to select better individuals. Higher mean and range for different yield and juice quality traits were also recorded by Kumar et al., 2018.

\section{Genetic variability}

Results revealed that phenotypic variances were higher than genotypic variances for all the traits under study which may be due to the non-genetic factor that played an important part in the manifestation of these traits. For all the traits the value of phenotypic coefficient of variation was found higher than genotypic coefficient of variation indicating the influence of environment on the expression of these traits. The narrow difference between PCV and GCV values and the lower values of ECV for all traits indicated little influence of the environment. GCV and PCV values were categorized as low $(0-10 \%)$, moderate (10$20 \%$ ) and high (above 20\%) as indicated by Sivasubramanian and Menon (1973). Higher GCV and PCV values were observed for traits namely no of millable canes (20.87 and
22.00), Cane yield (23.64 and 25.02) and CCS yield (24.30 and 26.02). Moderate GCV and PCV were observed for No of tillers, Single cane weight, and CCS\% and only moderate PCV for cane height and cane diameter. Low GCV and PCV were observed for the remaining traits. For effective selection presence of variability is a pre-requisite and it is both nature and magnitude of variability which decide progress of a breeding programme.

Higher values of GCV, PCV and narrow difference between them provide a good indication of the genotypic potential that allows a breeder to practice effective selection in desired direction. These results were found in agreement with the earlier findings of Anbanandan et al., (2018), Singh et al., (2015) and Bora et al., (2014). Low GCV values indicated the presence of less variability and these traits are difficult to improve by selection only. Lower GCV values for germination $\%$, cane diameter and brix \% were also observed previously by Agrawal and Kumar, 2017.

Table.1 Analysis of variance of augmented block design for thirteen traits in C2 generation sugarcane clones

\begin{tabular}{|c|c|c|c|c|c|c|c|}
\hline Source of Variation & DF & $\begin{array}{c}\text { Germination } \\
\mathbf{\%}\end{array}$ & $\begin{array}{c}\text { No of tillers } \\
\mathbf{( 0 0 0} / \mathbf{h a})\end{array}$ & $\begin{array}{c}\text { NMC } \\
\mathbf{( 0 0 0 / h a )}\end{array}$ & $\begin{array}{c}\text { Single cane } \\
\text { WT }(\mathbf{k g})\end{array}$ & $\begin{array}{c}\text { Cane } \\
\text { Height }(\mathbf{m})\end{array}$ & $\begin{array}{c}\text { Cane Diameter } \\
(\mathbf{c m})\end{array}$ \\
\hline Block & 5 & $70.527 * *$ & $748.005^{* * *}$ & $788.788^{* * *}$ & $0.123^{* * *}$ & 0.032 & $0.214^{* *}$ \\
\hline Entries & 148 & $45.899^{* *}$ & $344.154 * * *$ & $255.876^{* * *}$ & $0.044^{* * *}$ & $0.112^{*}$ & 0.077 \\
\hline Checks & 4 & $240.185^{* * *}$ & $627.735^{* * *}$ & $437.695^{* * *}$ & $0.063^{* * *}$ & $0.289^{* *}$ & 0.041 \\
\hline Varieties & 143 & $35.046^{* *}$ & $360.872^{* * *}$ & $279.573^{* * *}$ & $0.048^{* * *}$ & 0.106 & $0.086^{*}$ \\
\hline Checks vs. Varieties & 1 & $820.706^{* * *}$ & -3180.853 & -3860.077 & -0.572 & $0.266^{*}$ & -1.025 \\
\hline Error & 20 & 15.407 & 38.798 & 24.165 & 0.006 & 0.056 & 0.046 \\
\hline
\end{tabular}

\begin{tabular}{|c|c|c|c|c|c|c|c|c|}
\hline Source of Variation & DF & Brix\% & Polarity & Sucrose \% & Purity \% & CCS\% & Cane yield & CCS yield \\
\hline Block & 5 & $5.740^{* * *}$ & $108.161^{* * *}$ & $5.897 * * *$ & $246.351^{* * *}$ & $6.598^{* * *}$ & $2031.318^{* * *}$ & $84.191^{* * *}$ \\
\hline Entries & 148 & 0.742 & $47.047^{* * *}$ & $2.706^{* * *}$ & $54.127 * *$ & $2.556^{* * *}$ & $381.215^{* * *}$ & $14.421^{* * * *}$ \\
\hline Checks & 4 & 0.812 & $80.917 * * *$ & $5.212^{* * *}$ & $85.384^{* *}$ & $4.817^{* * *}$ & $979.826^{* * *}$ & $49.709^{* * *}$ \\
\hline Varieties & 143 & 0.901 & $48.783^{* * *}$ & $2.793^{* * *}$ & $61.817^{* * *}$ & $2.696^{* * *}$ & $437.562^{* * *}$ & $16.377 * * *$ \\
\hline Checks vs. Varieties & 1 & -22.148 & -336.765 & -19.740 & -1170.636 & -26.387 & -10070.938 & -406.479 \\
\hline Error & 20 & 0.520 & 8.397 & 0.491 & 15.511 & 0.469 & 40.624 & 1.820 \\
\hline
\end{tabular}

*significance at $5 \%, * *$ significance at $1 \%, * * *$ significance at $0.01 \%$, NMC- no of millable canes, CCS-commercial cane sugar. 
Table.2 Various selection parameters for different traits in C2 generation sugarcane clones

\begin{tabular}{|l|l|l|l|l|l|l|l|l|l|}
\hline SNo & Characters & Mean & Range & GCV & ECV & PCV & $\mathbf{H}^{2} \mathbf{b}$ & GA & GA \% of mean \\
\hline $\mathbf{1}$ & Germination\% & 42.90 & $30.00-58.33$ & 9.78 & 9.39 & 13.56 & 0.52 & 6.08 & 14.54 \\
\hline $\mathbf{2}$ & $\begin{array}{l}\text { No of tillers (000 } \\
\text { /ha) }\end{array}$ & 85.41 & $48.89-140.00$ & 19.22 & 7.23 & 20.54 & 0.88 & 31.92 & 37.06 \\
\hline $\mathbf{3}$ & NMC (000/ha) & 70.64 & $37.78-128.89$ & 20.87 & 6.96 & 22.00 & 0.90 & 28.81 & 40.79 \\
\hline $\mathbf{4}$ & $\begin{array}{l}\text { Single cane weight } \\
\text { (kg) }\end{array}$ & 1.11 & $0.70-1.80$ & 16.94 & 6.86 & 18.28 & 0.86 & 0.36 & 32.34 \\
\hline $\mathbf{5}$ & Cane height (m) & 2.27 & $1.48-3.17$ & 8.97 & 10.42 & 13.75 & 0.43 & 0.28 & 12.06 \\
\hline $\mathbf{6}$ & Cane diameter $(\mathrm{cm})$ & 2.33 & $1.68-3.34$ & 7.96 & 9.20 & 12.17 & 0.43 & 0.25 & 10.74 \\
\hline $\mathbf{7}$ & Brix\% & 20.49 & $18.00-23.00$ & 2.79 & 3.53 & 4.50 & 0.38 & 0.73 & 3.56 \\
\hline $\mathbf{8}$ & Polarity & 77.95 & $55.00-90.00$ & 7.57 & 3.74 & 8.44 & 0.80 & 10.83 & 13.97 \\
\hline $\mathbf{9}$ & Sucrose \% & 18.75 & $13.26-21.47$ & 7.51 & 3.76 & 8.39 & 0.80 & 2.58 & 13.83 \\
\hline $\mathbf{1 0}$ & Purity \% & 91.59 & $68.00-102.44$ & 6.86 & 4.31 & 8.10 & 0.72 & 10.96 & 11.98 \\
\hline $\mathbf{1 1}$ & CCS\% & 13.18 & $7.86-15.52$ & 10.51 & 5.23 & 11.74 & 0.80 & 2.54 & 19.38 \\
\hline $\mathbf{1 2}$ & Cane yield & 77.89 & $39.11-140.00$ & 23.64 & 8.20 & 25.02 & 0.89 & 35.78 & 46.01 \\
\hline $\mathbf{1 3}$ & CCS yield & 14.60 & $5.82-27.40$ & 24.30 & 9.31 & 26.02 & 0.87 & 6.77 & 46.74 \\
\hline
\end{tabular}

GCV-Genotypic coefficient of variation, PCV- Phenotypic coefficient of variation, ECV-Environmental coefficient of variation, GA- Genetic advance

\section{Heritability (Broad Sense)}

The heritability was categorized as low (0$30 \%)$, moderate (30-60\%) and high (60 and above) as given by Robinson et al., 1949. A very high broad sense heritability estimates were recorded for most of the traits viz., no of tillers (88\%), no of millable canes $(90 \%)$, single cane weight (86\%), sucrose percent (80\%), CCS percent $(80 \%)$, cane yield $(89 \%)$ and CCS yield (87\%). Moderate values were observed for Germination percent, cane height, cane diameter and brix percent. The heritability (broad sense) plays a vital role in breeding for crop improvement and gives an indication of repeatability of performance if selection is practiced for the particular trait. Higher heritability in broad sense for no of tillers, no of millable canes, cane height, cane diameter, sugar yield and cane yield was also reported by Neelofer and Kumar (2017), Negi et al., (2017a) and Patil and Patel (2017).

Genetic advance as percent of mean (GAM)

Genetic advance as per cent of mean (GAM) exhibited considerable variation for all the thirteen traits studied. It was categorized as low $(0-10 \%)$, moderate $(10-20 \%)$ and high (20 and above) as given by Johnson et al., 1955. Higher values of GAM were recorded for no of tillers (37.06 \%), no of millable canes (40.79\%), Single cane weight (32.34 $\%)$, Cane yield (46.01\%) and CCS yield (46.74\%). Moderate GAM was observed for germination percent, cane height, cane diameter, polarity, sucrose percent, purity percent and CCS percent. The heritability estimates are more useful when expressed in terms of genetic advance. High heritability with high GAM were reported for no of tillers, no of millable canes, Single cane weight, cane yield and CCS yield. These characters show additive gene action and improvement through direct selection could be possible for these characters. These results are in accordance with the earlier findings of Pandey et al., (2018), Negi et al., (2017b) Bora et al., (2014) and Chaudhary (2001).

From the present study it can be concluded that higher amount of genetic variability was present among the clones for all the traits. There was narrow difference between GCV and PCV values for no of tillers, no of 
millable canes, single cane weight, commercial cane sugar per cent, cane yield and commercial cane sugar yield indicate that these traits were less influenced by environment. High heritability coupled with high genetic advance reported for no of tillers, no of millable canes, Single cane weight, cane yield and CCS yield. Hence, improvement through direct selection could be possible for these traits.

\section{References}

Agrawal, R.K. and Kumar. B. (2017). Variability, Heritability and Genetic Advance for Cane Yield and its Contributing Traits in Sugarcane Clones under Waterlogged Condition. Int.J.Curr.Microbiol.App.Sci., 6(6): 1669-1679.

Anbanandan, V. and Eswaran, R. (2018). Genetic variability, heritability and genetic advance in sugarcane. International Journal of Recent Scientific Research, 9(2): 24217-24219.

Bairwa, A.K., Ram, R., Neetu, Jeena, A.S., Singh, K. and Singh, S.P. (2017). Estimation of the Extent of Variability for Different Morphological and Juice Quality Characters Among Early Generation Sugarcane Clones. Int.J.Curr.Microbiol.App.Sci., $\quad$ 6(2): 1272-1278.

Bora, G.C., Goswami, P.K. and Bordoloi, B.C. (2014). Studies on variability and character association in sugarcane (Saccharum spp) under rainfed condition of North Eastern India. Direct Research Journal of Agriculture and Food Science (DRJAFS), 2(5): 55-59.

Burton, G.W. and DeVane, E.W. (1953). Estimating heritability in tall Fescue (Festuca arundinacea) from replicated clonal material. Agronomy Journal. 45: 478-81.

Chaudhary, R.R. (2001). Genetic Variability and Heritability in Sugarcane. Nepal Agric. Res. J., 4(5): 56-59.

Federer, W. T. (1956). Augmented (or hoonuiaku) designs. Hawaiian Planters' Record LV., (2): 191-208.

Gupta, V., Raghuvanshi, S., Gupta, A., Saini, N., Gaur, A., Khan, M. S. and Suman, A. (2010). The water-deficit stress-and red-rot-related genes in sugarcane. Functional \& integrative genomics, 10(2): 207-214.

Jayashree, J., Selvi, A. and Nair, N.V. (2010). Characterization of resistance gene analog polymorphisms in sugarcane cultivars with varying levels of red rot resistance. Electronic Journal of Plant Breeding, 1(4): 1191-1199.

Johnson, H.W., Robinson, H.F. and Comstock, R.E. (1955). Estimates of genetic and environmental variability in soybeans. Agronomy Journal.47(7): 314-318.

Kumar, P., Pandey, S.S., Kumar, B., Kamat, D.N. and Kumar, M. (2018). Genetic variability, heritability and genetic advance of quantitative traits in sugarcane. International Journal of Chemical Studies, 6(3): 3569-3572.

Lush Jay L. (1949). Heritability of quantitative characters in farm animals. Hereditas, 35(1): 365-375.

Menossi, M., Silva-Filho, M.C., Vincentz, M., Van-Sluys, M.A. and Souza, G.M. (2008). Sugarcane Functional: Gene Discovery for Agronomic Trait Development. International Journal of Plant Genomics, 1-11.

Neelofer, S. and Kumar, B. (2017). Estimation of Variability in Red Rot Inoculated and Un- Inoculated Early Maturing Sugarcane Clones for Cane Yield and Juice Quality Traits. Int.J.Curr.Microbiol.App.Sci., $\quad$ 6(10): 2347-2359.

Negi, A.S., Singh, S.P., Jeena, A.S. and Khan, K.A. (2017b). Estimation of genetic 
variability and heritability parameters in early generation clones of sugarcane (Saccharum species complex). Frontiers in Crop Improvement, 5(2): 96-100.

Negi, A.S., Singh, S.P., Jeena, A.S. and Talha, M. (2017a). Estimation of variability parameters in early generation general collection progenies of sugarcane (Saccharum species complex). International J. Agriculture Innovations and Research, 6(1): 188190.

Pandey, D., Singh, S.P., Jeena, A.S., Khan, K. A., Tabassum, Negi, A. and Koujalagi, D. (2018). Study of Genetic Variability, Heritability and Genetic Advance for Various Yield and Quality Traits in Sugarcane Genotypes (Saccharum officinarum). Int.J.Curr.Microbiol.App. Sci., 7(4): 1464-1472.

Patil, P.P. and Patel, D.U. (2017). Study of Genetic Variability and Heritability in Sugarcane. International Journal of Current Microbiology and Applied Sciences, 6(9): 3112-3117.

Robinson, H. F., Comstock, R. E., and Harvey, P. H. (1949). Estimates of heritability and the degree of dominance in corn. Agronomy journal, 41:353-359.
Sharma, R. and Tamta, S. (2015). A Review on Red Rot: The "Cancer" of Sugarcane. J. Plant Pathol. Microbiol., S1: 003. doi:10.4172/2157-7471.S1003.

Singh, M., Mishra, D.K., Shukla, R.S., and Samaiya, R.K. (2015). Variation and heritability for some quality characteristics and grain yield in bread wheat (Triticuma estivum L.). Trends in Biosciences, 8(1): 68-70.

Singh, R., Jeena, A. S., Singh S. P. and Khan, K. A. (2015). Genetic variability and heritability studies in early generation clones of sugarcane (Saccharum sp. Complex). Frontiers in Crop Improvement, 3(2): 185-186.

Sivasubramanian, S., and Menon, M. (1973). Heterosis and inbreeding depression in rice. Madras Agric. J., 60: 1139.

Spencer, G. L. and Meade, G. P. (1955). Cane Sugar Hand Book. JWiley and Sons, N.Y.Sugar India, 2018.

Tabassum, Kumar, A., Kumar, A., Pangti, L. and Joshi, A. (2017). Evaluation of genetic variability in bread wheat (Triticum aestivum L. em Thell) genotypes. Bull. Env. Pharmacol. Life Sci., 6(3): 309-313.

\section{How to cite this article:}

Tabassum, A.S. Jeena, Deepanker Pandey, Deepak Koujalagi and Singh, S.P. 2019. Study of Selection Parameters for Different Yield and Juice Quality Parameters in Sugarcane (Saccharum Sp. complex). Int.J.Curr.Microbiol.App.Sci. 8(06): 1149-1155. doi: https://doi.org/10.20546/ijcmas.2019.806.142 